\title{
Partnerships between Foreign Agencies and Civil Society Organisations in Lesotho: A Marriage of Convenience
}

\author{
Johnson Lineo Rose \\ Department of Adult Basic Education \& Youth Development, School of Educational Studies, College of Education, University of South \\ Africa, South Africa
}

Copyright $(2016$ by authors, all rights reserved. Authors agree that this article remains permanently open access under the terms of the Creative Commons Attribution License 4.0 International License

\begin{abstract}
Lesotho is a country completely surrounded by South Africa. Since independence in 1966 the country attracted a lot of foreign aid interventions in most of its development programmes, including those channelled to civil society organisations. This research is a case study of one indigenous community-based organisation (CBO) in the northern part of the country. The aftermath of the massive Lesotho Highlands Water Project (LHWP) also created collaboration and partnerships with international donor organisations. This study investigated the impact of foreign aid interventions and donations to the country and the partnerships created with civil society organisations in Lesotho. The qualitative design through a case study approach to research identified an indigenous $\mathrm{CBO}$, in the northern part of Lesotho within the vicinity of the LHWP to investigate foreign aid funding models and partnerships with civil society organisations. This is a study conducted over an extended period and its accounts give a series of interviews, focus group interviews, transect walks to some community development projects areas. The study used a qualitative inquiry where the Boseele $\mathrm{CBO}$ was used as a case study revealing its history with partnerships over 10 years of its existence. The results were analysed thematically, chronologically and narratively and the CBO's successes with Canadian International Development Agency (CIDA) funding reflected positive foreign aid contribution towards the work of civil society organisations and that of community development. However, setbacks and lack of continuity with some projects questioned some of the funding models of some foreign agencies. Foreign aid partnerships and success with Civil Society Organisations and in community development should not be a marriage of convenience, but culminate in a spirit of collaboration, human capital development and benefits of civil society and community ownership. While the study cannot make claims to provide solutions to the funding models and challenges in each, the purpose of this study was achieved because it identified and obstacles that civil society organisations face, while they strive to advance their social mandate of serving their communities with meagre resources at their disposal.
\end{abstract}

Keywords Capacity Building, Foreign Agencies, Partnerships, Civil Society Organisations, Lesotho Highlands Water Project

\section{Introduction}

One of the main economic development projects in Lesotho from 1986 was the Lesotho Highlands Water Project (LHWP). The project is a massive multi-billion rand dam construction and engineering project undertaken by Lesotho and South Africa. The project was inaugurated in 1986 by the governments of the two countries and was essentially meant to supply surplus water from Lesotho to South Africa and generate electricity for Lesotho. The project's construction phases incorporate engineering, environmental and social impact facets which all sectors of the Basotho ${ }^{1}$ stand to benefit from. At its construction peak in phase 1, the project employed about 5000 Basotho (LHWP, 2000).The project's location was in the two Thaba-Tseka and Botha-Bothe districts ${ }^{2}$. Upon completion of the construction phase, the project retrenched more than half of its employees and retained only those who would maintain subsequent operational phases of the Project.

Within the context of Lesotho, civil society organisations (CSOs) are a social movement, a non-profit making autonomous and not for government entity with social responsibility and development mandate. Gastrow (2010), Lavergne \& Wood (2008) concur that civil society organisations' primary mandate is that of advancing developmental goals of communities, and not for making profits. Civil society organisations in Lesotho embrace an umbrella movement of non-governmental (NGOs),

1Lesotho is a country; Basotho are the people of Lesotho. The singular is Mosotho. The language is Sesotho.

2 Lesotho has ten administrative districts. Katse Dam is found in ThabaTseka district. 'Muela Hydropower Station in Botha-Bothe district supplies the country with hydro-electricity. Refer to the map of Lesotho on $\mathrm{p}$. 
community-based (CBOs), the faith-based (FBOs) organisations and non-state actors (NSAs). Cooperatives are also another form of civil society movement that is fully autonomous, but unlike others, it is a profit making entity for the benefit of its members. Trade unions are also defined as part of the CSOs conglomerate in Lesotho depending on their different registration membership status and classifications as stipulated in laws and policies of the country, (Strengthening Civil Society in Lesotho (SCIL), 2006; Johnson, 2011). In this article, the terms are used interchangeably. This article is a case study of a Community-Based Organisation (CBO), in the district of Botha-Bothe. The organisation was established and registered in 1997 by a group of concerned project and construction workers who were retrenched from the LHWP. The purpose of the organisation was to enable retrenched workers to address their household income needs through self-reliance, self-sufficiency and income-generating activities. Those needs would be addressed and realised after the members undertook retraining programmes and capacity building activities in their new role and responsibilities as members of the $\mathrm{CBO}$ movement. The majority of retrenched workers did not have the experience and the requisite skills to run income-generating projects, nor any experience in civil society organisations work and operations. Boseele is a registered CBO, and a legal entity, and accordingly it is an association. This study therefore makes reference to Boseele as a community-based organisation, a non-governmental organisation (NGO), a Non-State Actor (NSA) and an Association.

The study adopted a participatory action research in which members of the CBO and participants of this study contributed lessons and practices which were highlighted. The qualitative design methods used in data collection were interviews, observations and transect walks. Using a case study approach of the CBO over such an extended period of 10 years, the study represents the majority of life prototype, development and evolution of many CSOs in Lesotho and perhaps in other areas as also reflected in the literature section of the study. The data was analysed chronologically, narratively and thematically to illustrate different stages in its life as an NGO, and how NGOs existence is largely determined and influenced by foreign aid interventions. The five stages essential to effective development: espoused by Alan Rogers (1992) provides a theoretical framework to anchor the issues raised in the study.

\section{Orientation to the Study}

In its ten years of existence, the CBO's successes were heightened by achievements and improved livelihoods of some of its 250 members, but in 2005 serious challenges started to emerge. At the inception of the $\mathrm{CBO}$, the majority of the membership was from the former trade union movement while they were employed by the Lesotho Highlands Water Project (LHWP). Therefore the CBO started with the right footing because it had funds in the form of retrenchment and fringe benefit packages, and they contributed their dues to the Association which accumulated considerable funds and was cited in many national reports and CSOs best practices, (Boseele Nursery Project Document 2001). The Association had funds which members could borrow and return their loans with low interest. The Association became a model NGO in the country which initially had self-generated resources, and where members benefited directly from their investments.

In 2000, the association established a health care centre. The decision to establish a health centre was based on the identified gap in provision of private health services to the communities in the peri-urban and rural areas. Another reason was the human resources of some members who were nurses, health laboratory staff, pharmacists and physiotherapists. The health sector personnel were retrenched from the LHWP projects and they were highly skilled in health services. For three years, the health centre became the hallmark of the Association's success. The health centre was a model project, where the retrenched health officials from the LHWP formed themselves into a health team. The health centre provided primary health care services to the surrounding communities. Some of the state-of-the-art health machinery and equipment was purchased by the Association itself, with no assistance or intervention from the government.

Indeed the Association boasted a substantive financial base, and it became the attraction for community development and international foreign agencies, including financiers, (Boseele Association Annual Report, 2009). However, health services in many respects are basic social services which, even in developed countries, are subsidised by their governments. After running for three years, the health centre closed down due to lack of funds. After several efforts made by the Association in convincing the Government of Lesotho in subsidising the health centre, lack of funding prompted the Association to close its needed services to the communities, thus also starting to retrench their professional heath staff

\section{Problem Statement}

The start of problems surfaced around $2004-2005$, when some Executive members started taking employment elsewhere and took up other responsibilities and could not continue to lead the organisation. Meetings meant to coordinate and oversee the progress of the three projects were no longer held and strategic and administrative decisions were not made because meetings were not held. Those who vacated their positions within the executive could not be replaced because the meetings lacked quorums to pass decisions. Non-executive members lost interest as they felt side-lined. Members defaulted on their membership payments, membership declined and a low level of activity prevailed, with projects left unattended, some with little or 
no supervision. Seemingly, things were falling apart.

The internal problems that emanated as the organisation grew could be well attributed to their new experience they were encountering with foreign agencies, as work and activities evolved. According to one Executive member, if they had resources of their own, they could have managed well with fewer problems. But because they needed donors' resources, there was friction, as they had to learn how foreign agencies operated, thus importing knowledge and assets management approaches, which was a foreign knowledge to them. The two donor partners, MS-Lesotho and CIDA, were demanding in terms of administrative, programmatic and reporting requirements. Too wide a range of activities were taking place in various locations. A huge membership created a lot of administrative and management work load for executive members, the majority of whom were working as volunteers, in an effort to build their organisation. The management and administrative structures of the organisation comprised representatives and membership from the three main project areas/sites- the health centre; the nursery and farming projects. While the projects were located in the areas where there were members, some members still had to walk long distances for meetings, coordination of activities, reporting, management and administrative duties. With poor travel and roads infrastructure in Lesotho, the operation of the big projects run by volunteer membership was not very sustainable, (Setoi, 2012). It was the state of affairs that prompted this study to investigate the partnerships that exist between foreign agencies and CSOs.

\section{Research Focus and Questions}

The study focused on the role of development partners international foreign donors and civil society organisations in Lesotho. The research conducted addressed the following questions:

i) How has partnership ties of foreign agencies contributed in capacity development and knowledge base of civil society movement in Lesotho?

ii) What are the perceptions of civil society organisations regarding their capacity building and independence in managing their entities?

iii) Is the relationship between civil society and international organisations based on mutual respect or is it a marriage of convenience?

\section{Research Design and Methodology}

This is a qualitative research using a case study of a CBO that has gone through different phases of its growth in a period of 10 years. According to the membership register, in 2005 the association had 250 registered members, and that is the population for this study. A sample of 12 respondents was conveniently selected because of their availability, their knowledge of the history and issues of the association and their reach for research purposes. Among those who participated in the study were the association's office bearers and officials who could be reached. Research methods such as individual interviews and focus group discussions were used. Field observations and transect walks were conducted to some of the landmark projects of the association, and such observations were used to triangulate some interviews and focus group interviews held.

In some instances, member checks were done to ensure that the data were all accounted for, thus also ensuring reliability and validity of the data. Creswell (2014) says member-checking is an important technique in qualitative studies in determining whether the participants agree with previously noted information. It was not feasible to meet with foreign agencies because foreign officials are assigned certain contracts in their projects, however, Boseele was applauded for keeping their records and most of the information was documented in their reports. Meanwhile member-checking was done with the Association's members who participated in the study and the data was verified with them. Contents of documents, thematic, discourse, chronological and narrative techniques were used to analyse the data. Themes and historical chronology of events facilitated easier coding of the data into manageable units.

\section{Theoretical Framework and Literature Review}

Development is one of the most highly contested concepts, with many synonyms, expressions and semantics around it. International organisations like the World Bank, United Nations, and the International Monetary Fund (IMF), all have their definitions and operational mandates on development. The Cotonou Agreement (2003:15), for instance, interprets its development mandate/cooperation to reflect and mean: "The form of financial and technical assistance to support cooperation and [development] priorities, jointly agreed upon by the partners."

Rogers (1992) describes some of these deliberately planned and organised efforts as models or routes used in implementing and enhancing rural and community development programmes or projects. He further advises developers that there are critical stages essential to effective development and those steps form a model in which development becomes a long, winding process that requires patience, skills, time, commitment and desire to change. The Rogers' model is illustrated below.

Existing state----Awareness----Knowledge/skills, training, re-training, continuous learning----Action----Desired change or results

Figure 1. Stages essential to Effective Development (Rogers, 1992)

Models which Rogers (1992:120) advised against in 
community development are classified as bureaucratic, technocratic and direct-action routes. He added that in these processes/models, "omitting or skipping the awareness and the knowledge/skills stages," in which actual capacity building evolves, that culminates in "failure of projects." Where the critical stages of capacity building and ownership are skipped, rural or community projects lack sustainability, and often collapse due to these serious omissions. Development in this context refers to a continuation of what was discussed in capacity building. The continuum between capacity building and development is an infinite process. An individual learns and develops in many respects. People develop as individuals and as members of their communities and organisations or institutions. People and societies need economic, political and social developments in order to live and become better citizens.

Indabawa \& Mpofu (2005:35) define development as a deliberately planned and organised effort aimed at improving community life or solving particular problems in community. They further state that, if people do not see or interpret development programmes in ways that are significantly divergent from developers' intentions, then no matter how economically viable they are on paper; they may be completely impractical socially. With the best of intentions, all donors bring resources to the under-developed in order to succeed and profit the beneficiaries. This therefore confirms what this article is addressing that such success and profit should be a mutual agreement of the two parties. If communities do not see and interpret their success in the same manner as the developers, then it means there are no mutual understanding and development imperatives. In defining her understanding of development, Attwood, Leumer and Labuschagne (2001) inferred that development is a "process by which the members of a society increase their personal and institutional capacities to mobilise and manage resources to produce sustainable and justly distributed improvements in their quality of life consistent with their own aspirations", (Attwood, 2007:30, 81)

Lesotho is a small country that has never enjoyed any development from its previous colonisers. In 1994 Ferguson wrote that there were several reasons why Lesotho has remained at such a low stage of social and economic development....the British government did not really attempt to introduce any development....Lesotho is not merely poor; it is poor because it has remained at a... low stage of social and economic development. Similar observation was cited by Setoi(2012) of the lack of all forms of infrastructure rendering the country difficult in providing services. The European Union - Lesotho Governance of Non-State actors Project (LGNSP, 2010) describes the poverty levels of one of the districts, Botha-Bothe as;

Botha-Bothe is a district highly affected by poverty and this is because of drought which has taken more than 15 years, and...people have not been able to plough their fields. Poverty... is so severe that it resulted in many more problems such as: Hunger and starvation, alcohol and drug abuse, theft and armed robbery, prostitution and sex slavery. There are also problems of unemployment and retrenchments from the South African mines and firms... Most families in Botha-Bothe earn their living out of salaries which come from the mines. Poverty alleviation through agriculture and food production is very important at this particular time.

(LGNSP Project Document 2010:2.)

Despite the LHWP interventions in the district, many Basotho have still not benefited from the project, except maybe those who got employment like those who became members of the civil society in this study. One of the most significant factors that have affected the country is the impact of HIV and AIDS. The last two decades saw the country focusing its full attention on slowing the spread of the pandemic while other developmental issues were given little attention. Lesotho's HIV and AIDS prevalence rate was $29 \%$ in 2008. This puts Lesotho amongst the worst affected by the pandemic in the world....HIV/AIDS .....has a particularly strong impact on vulnerable groups, This is according to the Local Government Strategic Plan, (2008).

The state of the pandemic affected other developmental aspects severely. Coupled with the slow pace of development, Lesotho suffered a setback in having to deal with the consequences of the pandemic. It should be noted that Lesotho has become the second in the world of the countries most affected by the pandemic. This study observes with great concern that the country's under-development status has not changed for the better, since.

\section{Findings and Interpretations}

In 2001, a few years after its legal registration as an association, Boseele had a membership of about 150 men and women around the country. One of the founding members, Mr Oscar Maphuroane recalled that their first bank savings amounted to about M50 $000^{3}$ derived from subscriptions and membership fees and donations from various local, national and international organisations. Boseele regarded their big membership as a success and an indication of how their vision was shared by many. However, experience had shown them that having a large membership created challenges for a non-profit making organisation. In 2010 , the organisation had only 20 to 25 paid-up and active members. When they started, the subscription fee was M50. From 2009 it was increased to M200, (Boseele Annual Report, 2009). Members are regarded as such only when they have paid their dues. The executive members have learned through experience that quality membership was what they needed, not quantity. Their members now come

3M50 000 is equivalent to ZAR50 000 - about US $\$ 10000$ at the time. 
from the Botha-Bothe district alone, not countrywide, as was the case when they started.

\subsection{Perceptions on Capacity Development Interventions}

Maphuroane further emphasised that the strength or capacity of an organisation should not be judged or characterised by the number of members but the quality of service, commitment, participation, harmony and innovation they bring into the organisation. He also emphasised that civil society cannot survive without this important human resource which members bring into the sector. Similarly, civil society comprises individuals and membership organisations. The organisations survive because there are members who are neither employed nor paid but participate in development programmes meant to benefit themselves and their households, their organisations and their communities at large. If these people deem it fit to spend their resources - time, knowledge, labour - and to share what they get for the benefit of other community members, there must be some reward or incentive that motivates them to remain and maintain their membership. The research findings in this chapter revealed some of the benefits and challenges as experienced by other six members of Boseele.

Development projects do not succeed only because they are well designed and conceptualised. They are a result of effort, hard work, dedication and goodwill on the part of the individuals who plan them and those who implement them. Poor socio-economic conditions are a result of unfair distribution of country's resources. However, not all poor people are willing to bring about change and improved social and economic conditions. There are sayings ("teach a person to fish rather than give him a fish"; and: "you can take a horse to water but you can't make it drink") that show that empowerment is impossible when people do not make an effort. Civil society organisations thrive because of commitment of individual members, and it should be understood that not all members commit themselves to the ethos and principles of organisations in the same manner and at the same levels.

At the beginning of each year when learners enter the classroom, the educator cannot always predict which learners will graduate at the end of the year. At the level of civil society, many join as members but few reach their full potential. Boseele has showcased this view. The study confirmed that capacity building as an aspect of adult education was provided in several forms - non-formal, continuing and informal educational modes and using flexible methods and techniques. Many capacity building interventions were offered; skills development, information sessions, workshops, meetings, forums and workshops. These activities were presented at various levels by various agencies, according to their own goals and standards. Some individuals have benefited, but others did not. This perception is supported in Boseele (2004), where the Canadian international Development Agency (CIDA)'s impact in building the capacity of Boseele's members through various straining interventions for their new roles, was highlighted. Indeed Maphuroane agreed that from the interventions of most agencies in their life-time, CIDA made an indelible imprint he would not forget.

\subsection{Leadership Qualities in Partnerships}

Mr. Lebohang Mapheelle hails from the southern district of Lesotho known as Quthing, but he was employed by the Lesotho Highlands Water Project (LHWP) for eight years working as an apprentice pharmacist in the LHWP's Leribe Trauma Unit/ Hospital. Mapheelle does not have an academic qualification in pharmacy, but his more than 30 years' experience in dispensing medicines from his former job in the mines and the LHWP placed him at an advantage. The LHWP continued to provide on-the-job training for him. He earned a substantial monthly income compared with most of the project employees.

Traditional healing is still highly regarded by Basotho and hence Mapheelle has become a successful healer highly respected by his community. He took over the running, administration, resources and ownership of the centre. Other members were not happy with Mapheelle's inheritance of the organisation's resources. However, his argument was that the equipment was technical and would not benefit the organisation as only he had the expertise to use it. The equipment would become a "white elephant, benefiting nobody," he added. He continues to maintain the ethos of Boseele by being a successful farmer who owned many fields. He practiced sharecropping with other community members, often his patients, particularly those who could not afford to pay for health services. He spoke highly of his personal achievements and how Boseele has impacted on his success. He believed he would not have been successful if he had started alone. Boseele served as the platform for his success.

On partnerships the association had with international donors, Mapheelle reminisced that of all agencies they worked closely with, he could recall their cordial and mutual relationship and partnership with CIDA and MS-Lesotho. Although with the latter, serious problems were encountered. He recalled the support and capacity building activities that were conducted to equip them with skills through CIDA, and their success thereafter. On other donors, he was not keen to go into details of what transpired. This study however realised that CIDA's successful intervention could be attributed to the fact that, the organisation had their local contribution as well, while subsequently other donors came while their coffers were already dry.

Chief Lira-ha-li-bonoe Peete hailed from a royal and chieftaincy family, and he was a headman ${ }^{4}$. At the time of an interview he was 70 old. He was a founder member of Boseele and was considered the "institutional memory" of

4 Headman is subordinate to a chief. Headmen either come from the chieftainship families or clans, or can be elected by village elders. 
the association, as other members kept referring to him for the organisational history. He was a shop-steward in the LHWP and he seemed more informed and knowledgeable in many respects than other members of Boseele. During the interviews and in meetings, he seemed eloquent in the economic, political and environmental affairs of Lesotho and of other countries. Through his influence, Chief Peete was able to acquire the nursery project site from his half-brother.

Peete believed that non-formal education geared to self-sufficiency could be productive in enhancing people's ability to become self-reliant. Young people should be encouraged to join in civil society programmes. He said this in the light of the deteriorating economic conditions of the Basotho. "Basotho should not rely anymore on political or economic leadership that promotes employment opportunities against self-sufficiency and self-reliance." He was convinced that the National University of Lesotho's motto, "taking the university to the people," should be more realised than it was. Formal Adult Education provided by the university is not enough; more non-formal training that addresses needs and aspirations for self-sufficiency should be promoted for the rural Basotho. He said young people should join civil society organisations because, "they are free learning institutions, if one is eager to learn". However, he also realised how difficult it was if young people had to be breadwinners in their lives and homes. He was concerned about the child-headed households' phenomenon, where small children lose parents and in turn become young parents themselves.

Peete said there were five attributes typical of the Basotho. "Basotho are not successful as civil society organisations' members because the majority of us are botsoa (lazy); (jealous); masholu (thieves); balotsana (cheats); and $b a$ hloloa ke nako (poor time-keepers).

\subsection{The 2000 - 2005 Era of Challenges}

During 2000 to 2005, Boseele secured funding from the Danish Volunteer Service (DVS), later known as MS-Lesotho. The DVS-MS Lesotho was cited by all who were interviewed as another funding agency like CIDA which funded the organisation with a substantive amount of money. According to the treasurer, a sum of M350 000 (the equivalent of US\$50 000 then) was packaged specifically for a nursery project. It also provided technical support through one of its volunteers, (Project Design Document 2001). The project had two main objectives:

i) To unleash a potential of nursery products targeting at supplying communities, other development and government projects with seedlings for trees.

ii) The nursery project was to impart skills to the organisation's members while also generating funds for the sustainability of the organisation and its members' livelihoods.

The Project Document (Boseele Association 2001) states that the Danish (Ms-Lesotho) intention of providing technical support was to ensure that the local community and local government structures would take over the running and management of the project once the Danish technical support had left. Capacity building was to be provided to the project members to enable a smooth transition and proper handover. The Boseele members were to be provided with technical and leadership skills to ensure continuity and sustainability of the project. The process was meant to empower the members and community to continue and claim ownership of the project. A series of capacity building and training activities were conducted for Boseele members through the MS-Lesotho funding and with other service providers and partners. 'Mamotaung Lesoetsa, the treasurer at BoseeleNursery, however was concerned that instead of the said funding improving their lives for the better, it created more problems. "When members not employed in the nursery project started thinking others had more access to resources than they did, that created conflict, suspicion and mistrust," she said. Most of the people who criticised others were those who were idle and did not have much work. The project could not engage every member of Boseele. Those who knew little about the project created problems, confusion and conflict, and became a bad influence on others. 'Mamotaung said she experienced death threats at one stage, because some members who knew that she was the treasurer thought she and her family were benefiting from the project's resources, and that she was keeping money, resources and information from them.

On the other hand, 'Mamotaung showed us some wheelbarrows and garden tools which she herself confiscated from the project because she was still owed three months' wages, or rather stipend, when the MS-Lesotho funding came to an end. While she knew there were no more funds, she believed Boseele had funds which could have been used to pay her and four other employees. She said she was still bitter about her stipend, and she would not give back the wheelbarrows and garden tools to Boseele. As we walked along and towards the nursery project site, we saw beautifully-built gabions rehabilitating storm water. 'Mamotaung confirmed it was the result of their project development as the donga was growing bigger after every rainfall.

\subsection{Orphan and Child-headed Households}

Thabelang was a young man of 31 years who has just married. He was a member of the nursery project. Thabelang said he did not volunteer his services in the nursery project. He had to work to earn a living for his younger siblings. He joined the nursery project purely as a means of employment and to get money for survival. He left when he realised the workers were not paid. When World Vision (WV) came into the area he attended their meetings. After realising that the organisation would pay school fees and other needs of his siblings he continued to participate in its activities. He then left Boseele to join World Vision in order to access the promised benefits and resources. Apart from the World 
Vision programme, Thabelang said he also joined the political ruling party and carried its card. "When development projects are brought into new areas, job opportunities are given first to card-carrying members," he revealed. The study registered that comment with contempt it deserved. Political manipulation on poor people for development purposes should be shamed and stopped.

\subsection{Development Interventions for Immediate Needs}

Nkhono (meaning "grandmother") 'Makhahliso Monkhoane is an old woman born in 1924, a widow who lives with her three grandchildren, all of whom are orphaned. Her son, daughter and daughter-in-law died of AIDS some four years ago, leaving three orphans in her care. She is old and does not have another source of income except the government grant for senior citizens. Her M $150^{5}$ monthly grant is their only means of survival. She was a member of Boseele during the nursery project.

When World Vision came into the village, she joined its programme in search of assistance for her three orphaned grandchildren. "I became active with World Vision because I needed help and found it. Boseele failed me and I could not continue my membership. They used us. Why didn't they tell us that their organisation would only benefit young and able people?" She said she felt deceived and discriminated against, because of her age. In Lesotho, WV was established in 1976. It is known worldwide for its efforts to end hunger through different projects such as food aid and distribution, advocacy and pleading the cause of the hungry. In Lesotho, WV states its commitment in partnering with the people of Lesotho individually and collectively to enhance their lives and to help enact sustainable solutions for the future of their communities, families and children. Starting with only three projects, WV-Lesotho grew to 49 development projects clustered into area development projects (ADPs) around the country. It was therefore not surprising that the old lady and the young man found more fitting support from WV programmes than with the longer term empowerment project of Boseele. WV addressed immediate needs, such as food aid and school fees and was more relevant to them than Boseele. World Vision was applauded for its work with orphans and vulnerable children.

\subsection{When Development Becomes a Marriage of Convenience}

These discussions have brought us to the end of this study. The results have added more evidence in support of other previously written experiences reflected by the study. In response to the question, yes, foreign aid makes a difference, depending on how one looks at the development dynamics and emerging social and economic issues in society/societies. Foreign aid alone does not make social and economic needs

5M150/R150 - about \$21 a month (\$1/R10 rate) disappear; foreign aid can stimulate change in communities that are also willing to benefit from it. Foreign aid is the result of other macro developmental, political and economic issues in society.

Another aspect of this study was how important an indigenous knowledge and participation in carrying out a social development agenda, which civil society organisations' members bring into community development projects, are. Often this important aspect is overlooked or taken for granted in the life cycle of organisations, yet it remains very valuable. While foreign funding contributes largely to the growth of the organisations in terms of assets and support Boseele's challenges faced in sustaining the nursery project showed that the two learning cultures - the indigenous and the imported, foreign cultures - should be harmonised. This is an important learning process for CSO members, who usually have to adjust in order to accommodate and augment their knowledge and dynamics with foreign agencies.

\section{Conclusions and Recommendations}

Maphuroane's observations that the capacity of an organisation should not be judged or characterised by the number of members but the quality of service, commitment, participation, harmony and innovation they bring into the organisation, were shared by this study, and that was based on the interviews conducted for this research. Some members have benefited more than others, depending on the number of reasons, and individuals astuteness. All testimonies acknowledge that dedicated members of organisations are the backbone of such organisations, and they ensure that their organisation was able to survive through their actions and commitment while others left when things fell apart. Individuals with compatible goals to those of their organisations are able to sustain their organisations as long as they economically benefit as well. The conclusion and recommendations of this study are divided into four headings as follows:

- Diverse environments and frameworks

- Empowerment of individuals through civil society programmes

- Power dynamics in development projects

- Development model: A marriage of convenience?

\subsection{Diverse Environments and Frameworks}

Development programme of civil society organisations should be evaluated within their legal, economic and social frameworks. Civil society organisations are established to pursue developmental goals of individual members and to enhance social benefits for communities. This study discovered that in Lesotho, economic benefits for volunteer members are critical and should be factored in to any development project.

The literature review pointed to the diverse environments in which civil society organisations work with limited 
technical resources. Diversities within development interventions demand that stakeholders talk to each other, particularly where they work with the same communities. Impact of donor interventions in development projects would be better realised and maximised if all stakeholders governments, NGOs, local government and communities work together to ensure the success of community projects and improved livelihoods of those who directly carry those development activities. Based on the Boseele's experiences, the study concludes that empowerment of communities is achievable and can lead to sustainable development and ownership of development projects, where partnerships are based on mutual respect and recognition of each other's strengths and abilities.

\subsection{Empowerment of Individuals}

The story of Mapheelle's health service provision illustrated an empowered individual whose bold decision-making earned him good results and a small fortune. Morena Peete managed to climb the ladder through civil society organisations for his own benefits. He continued to benefit from the organisation because he was able to make personal sacrifices while advancing projects for the organisation. Khanare and his team on the other hand, were not able to continue the nursery project. The project has remained an unused community liability while there were trained members who could continue benefiting from its operations. In this instance the study recognised two sets of individuals with resources at their disposal; using such resources to benefit themselves, the other one leaving everything to collapse. Their situations were similar and they could have easily continued producing seedlings and selling to their customers, but they did not. This shows that not all individuals act in the same manner, or are similarly empowered. If individuals are not empowered and not economically motivated to undertake community work, empowerment and ownership of projects is compromised, since people have to deal with their own bread and butter issues first. Communities will not sustain projects that are not beneficial to their social and economic needs. The issue of how immediate community needs should be addressed without compromising empowerment principles is critical. Incentives, handouts and social grants are an answer to this dilemma, as long as they lead to long-term sustainable development projects. This research confirmed that if an individual is empowered economically, then empowerment within organisations can be realised through such individuals.

\subsection{Power Dynamics in Development Projects}

Empowerment is a result of many factors and reasons. Why some people are empowered and others are not, is not a matter of logic; people are not the same. Empowerment depends on various factors. Considering the two cases of Mapheelle and Peete, one would be inclined to say urban people are more likely to be empowered than rural ones. Then empowerment could be associated with urban-rural divide and influence. The research findings suggest that perhaps adult males like Mapheelle, Morena Peete and Khanare are better placed to take advantage of opportunities for empowerment because of their privileged position in Basotho society in relation to rural counterparts. Rural people felt incapacitated to take risks perhaps because dependency syndrome is more ingrained in rural areas than in urban areas. The two urban members - Mapheelle and Morena Peete - seemed to have taken bold decisions, while another Boseele member said he was not exposed to such networks and support structures. One can infer that urban people are exposed to a wider range of social relationships and role models than rural people. Seemingly this study concludes that better-resourced people and those poorly-resourced behave differently in participating and maintaining their participation in development projects. The rich-poor power dynamics and imbalances are ingredients in development programmes. The experiences of the nursery project therefore suggest that poor communities could not sustain projects which did not generate income for themselves as individuals.

Donor prescriptions in the form of resources, authority, decision making on how projects should be run and whose knowledge base is more hegemonic than the other - these issues are not new to researchers. These are foreign/local power imbalances and yield power dynamics in development projects. The results of this study have been known for some time. They remain international, political, economic, dynamic and macro issues. They have direct implications for development projects. If governments, civil society organisations and foreign partners are informed and aware of these "beyond-us" dilemmas, and keep doing what they think is ethical and morally correct and just, social and economic injustices and inequalities in poverty, food insecurities and unemployment could be minimised.

\subsection{Development Model: A marriage of Convenience?}

Within a period of 10 years, the Association had had five donor interventions or partnerships - CIDA, MS- Danish Lesotho, World Vision, A consortium of Irish Aid and ActionAid Lesotho and the European Union (LGNSP). According to Maphuroane, all these interventions came with "strings attached". These strings were conditions stipulated in the memoranda of agreement. Interestingly, all donors' priorities were on how they were going to capacitate the Association on the running of projects in their funding roll. "The training and capacity building was never on the needs and benefits of the local CBO," he added. This study confirmed that the development agenda with foreign aid injection largely determine their benefits not those of the recipient organisations. This is the marriage of convenience partnerships that this article is addressing. While this study is of the view that foreign aid alone does not make social and economic needs disappear, foreign aid can stimulate change 
in communities that are also willing to benefit from it. The study recognised that foreign aid is the result of other macro developmental, political and economic issues in society, which may be interpreted differently by the foreign agencies and their CBO development partners.

Another important aspect of this study was how important an indigenous knowledge and participation in carrying out social development agenda, which civil society organisations' members bring into community development projects. Often, this important aspect is over-looked or taken for granted in the life-cycle of organisations, yet very valuable. While foreign funding contributes largely to the growth of the organisations in terms of assets and monetarily strengthening, the challenges Boseele faced in sustaining the nursery project showed that the two learning cultures - the indigenous and the imported, foreign cultures should be harmonised as important learning processes for CSO members, who usually have to adjust in order to accommodate and augment their knowledge and dynamics with foreign agencies. One of the findings which were beyond the scope of this study, yet important was how Chief Peete noted the cultural beliefs, habits, values and aspirations of Basotho in facilitating a better understanding of the Basotho's views on development projects and those of the civil society organisations. This view could be taken as food for thought by foreign agencies before embarking on development mandate and interventions with CSOs in Lesotho, if their partnerships would be mutual and beneficial. Until now, it seems the partnerships between foreign agencies and Lesotho civil society organisations is business as usual, a marriage of convenience and perhaps another form of foreign dominance and supremacy over less developed partners and countries.

\section{REFERENCES}

[1] Attwood G., Leumer W., \& Labuschagne S. 2001. Views on the REFLECT approach to development: Possibilities for participation? A case study of REFLECT in Lesotho. In Conference Report. The Role of Adult Education in Sustainable Development (pp. 75-82). Johannesburg: Project Literacy.
[2] Boseele Association. 1997. Constitution amended in 2005. Botha-Bothe.

[3] Boseele Association. 2001. Boseele-Nursery Project Document, Memorandum of Understanding. MS-Lesotho, Maseru.

[4] Boseele Association. 2004a. Audit report 2000-2004. Botha-Bothe.

[5] Boseele Association.2004b. Boseele Agriculture and Share-Cropping Farming, Memorandum of Agreement. CIDA, Maseru.

[6] Boseele Association. 2009. Annual General meeting 2009. Botha-Bothe.

[7] Boseele Association.2010. Boseele Animal Husbandry Project. European Union. LGNSP, Maseru.

[8] Creswell J.W. 2014.Research Design.4 ${ }^{\text {th }}$ Ed. SAGE Publications Inc. New York.

[9] Gastrow, S. 2010. Nonprofit sector provides sustainable solutions where business fails.Available at: http://www ngopulse.org/article(accessed on 30 June 2010).

[10] Indabawa, S \&Mpofu, S. 2006. The social context of adult learning in Africa. Cape Town: Pearson Education.

[11] Johnson, L.R. 2011.Does foreign aid makes a difference? A case study of the Boseele Association in Northern Lesotho. Unpublished MEd Dissertation. University of the Witwatersrand, Johannesburg.

[12] Lavergne, R., \& Wood, J. 2008. CIDA, civil society and development. A discussion paper.. Ottawa: Institute on Governance

[13] Lesotho Highlands Water Project Report (2000), Volume 8, LHDA, Maseru.

[14] Ministry of Local Government and Chieftainship. 2008. Strategic plan 2009-2013, Volume 1. GTZ, Maseru.

[15] Rogers, A. 1992.Adults learning for development. London: Education for Development.

[16] SCIL, 2006.Capacity assessment report: the state of civil society organisations in Lesotho. Maseru: Ntlafalang Consultants.

[17] Setoi M. 2012.Youth and adult learning and education in Lesotho. Open Society Initiative for Southern Africa (OSISA). 